\title{
MASSIVE OPEN ONLINE COURSES (MOOC) FOR TEACHING PORTUGUESE FOR FOREIGNERS: A CASE STUDY
}

\author{
Dr. Airton ZANCANARO \\ Catarinense Federal Institute (IFC) \\ Sao Bento do Sul, Brasil \\ Dr. Maria Jose Carvalho de Souza DOMINGUES \\ Management Department, Regional University of Blumenau \\ Blumenau, Brasil
}

\begin{abstract}
Education is experiencing a period of change and the traditional models of education adopted by universities need to go through innovative processes to democratize knowledge, attract new learners and optimize resources. The use of Open Educational Resources (OERs) and Massive Open Online Courses (MOOC) can contribute to such changes. However, studies on the reuse of OERs and language courses in the MOOC format are still scarce. To this end, the aims of this study are (a) to verify whether the OER production cycle proposed by Zancanaro (2015) in his framework could be used in part for the production and supply of MOOCs and (b) to present the production and to offer a process of the Portuguese Teaching MOOC for Foreigners (MOOC-PFL), developed at the Regional University of Blumenau. This is a case study that shows a production and offers cycle comprising the phases of analysis and design, coding, evaluation, dissemination and offering. Considering it was the first experience of the University with a MOOC course, it exceeded expectations, provided an increase in the institution's and city's visibility, contributed to the demystification of the OER use by the production and offer team and generated incentives for the production of new levels.
\end{abstract}

Keywords: MOOC, Portuguese course for foreigners, Open Educational Resources, Regional University of Blumenau

\section{INTRODUCTION}

Education is experiencing a period of change (Mihaescu, Vasiu, \& Andone, 2014) and the traditional models of education adopted by universities are under discussion nowadays. The institutions need to experience new teaching and learning strategies to attract students, so they can have relevant and effective experiences during their training process (Sangrà \& Wheeler, 2013).

The use of technology in distance education (DE) can be strategic both for educational institutions and for students, since most of the information transmissions and interactions have been established through it (Nunes, Rissi, Nakayama, \& Pacheco, 2015). In the case of the institutions, with the decrease in government funding and the increase of society's expectations regarding teaching and research, such use provides survival conditions in the current scenario of changes and favors institutional growth (O'Connor, 2014). As for the students, it enables the creation of virtual contact networks (Burigo, Cerny, Teixeira, \& Marcelino, 2016) to exchange experiences, access and co-produce content available in online repositories and to participate in courses available on the Web.

The MOOCs make up the movement of changes in higher education, but they were not the first ones, says Nissenson and Shih (2015). Over recent years, several universities have 
developed and offered MOOCs for various reasons, being among them the dissemination and promotion of the institution, education cost reduction, expanding access to education, increasing revenue and conducting studies on innovation in the process of teaching and learning. However, one of the barriers to the production of MOOCs is its high initial cost, making it difficult for the smaller universities to build their own online courses and so to develop experience with this new course format.

For Weller (2014) the MOOCs, due to their emerging nature, require studies on how to produce and deliver open courses reusing existing materials in the OER format. Besides, according to Martín-Monje, Barcena, and Read (2014), there are few studies about language courses in MOOC format. It is noticed, for example, the absence of Brazilian Portuguese courses being offered for free in Coursera, edX and MiriadaX platforms.For such reasons, the aims of this study are (a) to verify whether the framework proposed by Zancanaro (2015) for the production of OERs focused on the dissemination of learning could also be fully used for the production and offer of MOOCs; (b) to present the production and offer process of an online open course for teaching Brazilian Portuguese for foreigners (MOOC-PFL) by means of OER, developed in the Regional University of Blumenau from June 2015 to March 2016, which was a production of a post-doctorate project.

The proposal for the MOOC-PFL was to produce a course at no extra cost to the University, in order to reuse existing OERs, to use the laboratory infrastructure already available in the institution for the production of new materials, to use applications available for free on the Web, both for video production and for the creation of interactive activities, and to offer the course using the MiriadaX platform, available for free in agreement.

This paper is organized as follows: in section 2, literature review: OERs, MOOCs and related work will be presented. Further, section 3 presents the methodology of the work and section 4 brings the results based on the MOOC production cycle. Section 5 shows the discussions and section 6 presents the conclusion and future studies.

\section{LITERATURE REVIEW}

Centered in the "openness" paradigm (Hylen, 2006), the term OER was created during the Forum on the Impact of OpenCourseWare for Higher Education in Developing Countries, promoted by UNESCO and held in Paris in 2002, as an alternative to other existing ones: "open courseware", "open learning resources" and "open teaching/learning resources" (UNESCO, 2002, p.24).

The beginning of the OER movement occurred in 2001, when the Massachusetts Institute of Technology (MIT), sponsored by the William and Flora Hewlett Foundation, made up and offered, in 2002, the project named MIT Open CourseWare - http://ocw.mit.edu/index.htm (Goldberg \& LaMagna, 2012; Weller, 2014). It aimed at offering, through a portal on the Web, classroom materials of subjects from the Undergraduate and Graduate Courses at MIT, produced by the scholars of the institution and under the Creative Commons license (Banzato, 2012; Q. Chen, 2010; Pantò \& Comas-Quinn, 2013).

The OER movement says that "[...] knowledge of the world is a public good and the technology in general and the Web in particular provide a unique opportunity for everyone to share, use and reuse knowledge" (Angell, Hartwell, \& Hemingway, 2011, p.257-258) and that "[...] shared knowledge is the basis of knowledge" (Santos-Hermosa, Ferran-Ferrer, \& Abadal, 2012, p.141).

The definition of OER has evolved over time and from the "OER Declaration of Paris in 2012", it follows that:

[...] teaching, learning and research materials in any medium, digital or otherwise, that reside in the public domain or have been released under an open license that permits no-cost access, use, adaptation and 
redistribution by others with no or limited restrictions. Open licensing is built within the existing framework of intellectual property rights as defined by relevant international conventions and respects the authorship of the work (UNESCO, 2012).

The MOOCs, which are types of OER are online courses open for anyone to access, free of charge, unlimited participation (Pujar \& Bansode, 2014; Spector, 2014) and having the accessibility and flexibility as key features (King et al., 2014; Parkinson, 2014). These courses are developed using the expertise of universities in distance education and in the production and availability of OERs (Clarke, 2013; Kumar, KanikaPhutela, NehaSrivastava, Singar, \& Ieee, 2013), being able to contribute in education since the new ones are used educational technologies associated with innovative pedagogies (Iqbal, Zang, Zhu, Chen, \& Zhao, 2014).

The term MOOC was created by Dave Cormier and Bryan Alexander (Iqbal et al., 2014; Stuchlíkova \& Kosa, 2013) to describe the course called "Connectivism and Connective Knowledge" in 2008 as an experimental method to test the Connectionist Learning Theory proposed by George Siemens and Stephen Downes (Eckerdal et al., 2014). However, from the course of "Artificial Intelligence", which was offered by Sebastian Thrum in 2011, attended by 160,000 people from 190 countries and completed by 23,000 of them, the MOOCs aroused greater interest in the media and the academy (Iqbal et al., 2014), which considered them as a radical or disruptive innovation in the different educational levels: educational, content, organizational and cultural (Levy \& Schrire, 2013).

The MOOCs can be classified into XMOOCs and cMOOCs (Comeau \& Cheng, 2013). The xMOOCs, adopt a behaviorist approach (Mihaescu et al., 2014) in which the education model follows what is already practiced in the traditional method of teaching, focusing on content or teacher (Chen, 2014). They can be easily accessed (Stikkolorum, Demuth, Zaytsev, Boulanger, \& Gray, 2014), they have the preference of the participants, possibly the discussions provided in the forums and learning tools available. While cMOOCs, based on the connectionist theory (Mihaescu et al., 2014), in which knowledge is distributed throughout the network and that learning is the ability of individuals to establish and use these networks (Leontyev \& Baranov, 2013; Rodriguez, 2013, 2014). In short, "cMOOCs focus on the creation and generation of knowledge while xMOOCs focus on duplication of knowledge" (Mihaescu et al., 2014, pp. 341). However, Martín-Monje et al. (2014) realize that currently there is a blend of CMOOC and XMOOC in the courses offered, in which part of a learning community is important to the participant, but not the main objective of it.

Because of their open nature, the MOOCs allow the institutions to reach an unlimited number of participants (Ahlberg, 2014), disseminate knowledge, create an educational space of experimentation in the online teaching and learning process, allow the brand awareness of the institution and contribute to the universities lose their fear to innovate in the teaching process (Stuchlíkova \& Kosa, 2013). Though, MOOCs are challenged by low completion rates and the lack of research regarding the effectiveness in promoting learning (Stark \& Pope, 2014). To this end, it is clear that in the production and supply of a MOOC there are several challenges to be overcome such as offering a course that considers the heterogeneity of a large number of participants; aggregating and engaging the interdisciplinary team; raising funds; defining technology infrastructure and reusing and developing new OERs (Claros et al., 2013).

Some research has been done in order to present experiences in the production and supply of MOOCs. One is described by Schmidt and McCormick (2013) and they report some lessons learned in the production and supply of the course "Pattern-Oriented Software Architecture for Concurrent and Networked Software" offered in 2013 in which there were over 31,000 subscribers and approximately 1,600 of those completed it. The time to prepare and manage the course was great, it was challenging and the diversity of 
participants was satisfying. However, there have been some technical problems in the use of the platform and limited access of some course participants. Martín-Monje et al. (2014) point out that in the MOOC of "Professional English", there were 23,424 registered participants, 19,076 started the course and 1,120 completed it. The authors identified the need to create mechanisms to substantially improve the interaction among participants. Finally, in the work by Ding et al. (2014) the authors presented data related to the course "Bioinformatics: Introduction and Methods" which had been conducted within 12 weeks, containing 43 study units and, at least, one video. That MOOC was offered twice: the first time in 2013, having 18,367 enrollments and 520 completions, and the second one in 2014, having 16,714 enrollments and 510 students completing the course.

\section{METHODOLOGICAL PROCEDURES}

This study is characterized as a descriptive case study, since it aims to show the process of production and supply of an open course to Teach Portuguese for Foreigners using OER, developed at the Regional University of Blumenau from June 2015 to March 2016.

We decided to make this MOOC available to socialize Portuguese as a foreign idiom around the world, to give learners a clear vision of the real language spoken and not only the grammatical structure and to improve the knowledge of learners who have studied it before. Also we tried to offer different strategies and tools to motivate e-learners through the whole course. We chose the xMOOC because it had the shape of a traditional class (videoclasses, interactive exercises and forums) besides offering easy access. In addition, through the activities carried out, we gave the participants the feeling of being part of a community of students of Portuguese for foreigners.

This work started with the aim to verify whether the framework for the production of OERs with a focus on dissemination of knowledge, proposed by Zancanaro (2015), could also be fully used for the production and offer of MOOCs. Another goal was to make University managers aware of the possibility to experiment an innovative educational practice and provide a way, in MOOC format, to fill the existing gap when it refers to courses of Portuguese as a Foreign Language (MOOC-PFL).

The framework for the production of OERs, proposed by Zancanaro (2015), is comprised of a production cycle that has the following stages: analysis and design, coding, using and evaluating, publishing and its requirements. During the process of production and offer of MOOC-PFL each of the four phases of the OER production cycle has been checked, evaluated and supplemented as needed.

Starting on the analysis and design phase, the team for the production and offer of MOOCPFL was composed, and it was established the general learning objectives, the target audience, the level of difficulty of the material, the technological infrastructure for the production and offer of the course and the type of use license. At this stage, materials were also selected (video, text and images), in OER type, which had a license of use compatible with the one already set for the course.

In the coding phase, the OERs identified in the previous step were grouped and remixed, and new ones were produced to form the course. To provide dynamism and interactivity to the course, it was sought for Web applications that would help participants understand the addressed issues. Thus, the material was published in the platform defined in the previous step.

After that, the course went through the evaluation phase, in which the production team together with the technical team of the selected platform verified the consistency and quality of the course and possible technical problems at runtime.

In the dissemination phase advertising campaigns were conducted using social networks, printed newspaper, news sites and blogs, telephone calls and e-mails sent to international educational institutions. In addition, the owner of the selected platform sent e-mails to its users. 
Finally, in the offer phase of MOOC-PFL, which took place over four weeks, from February 15 to March 15, 2016, there were email newsletters being sent, participants being followed up in the platform forums and in a group created in a social network. In addition, it was necessary to keep communicating with the technical team of the platform to make specific changes in the course and correct technical errors on the platform during the offer.

During this process it was found that the OER production cycle proposed by Zancanaro (2015), answers, in part, to the production and offer of MOOCs, being necessary to improve some phases and supplement the cycle with a supplying phase, as illustrated in Figure 1.

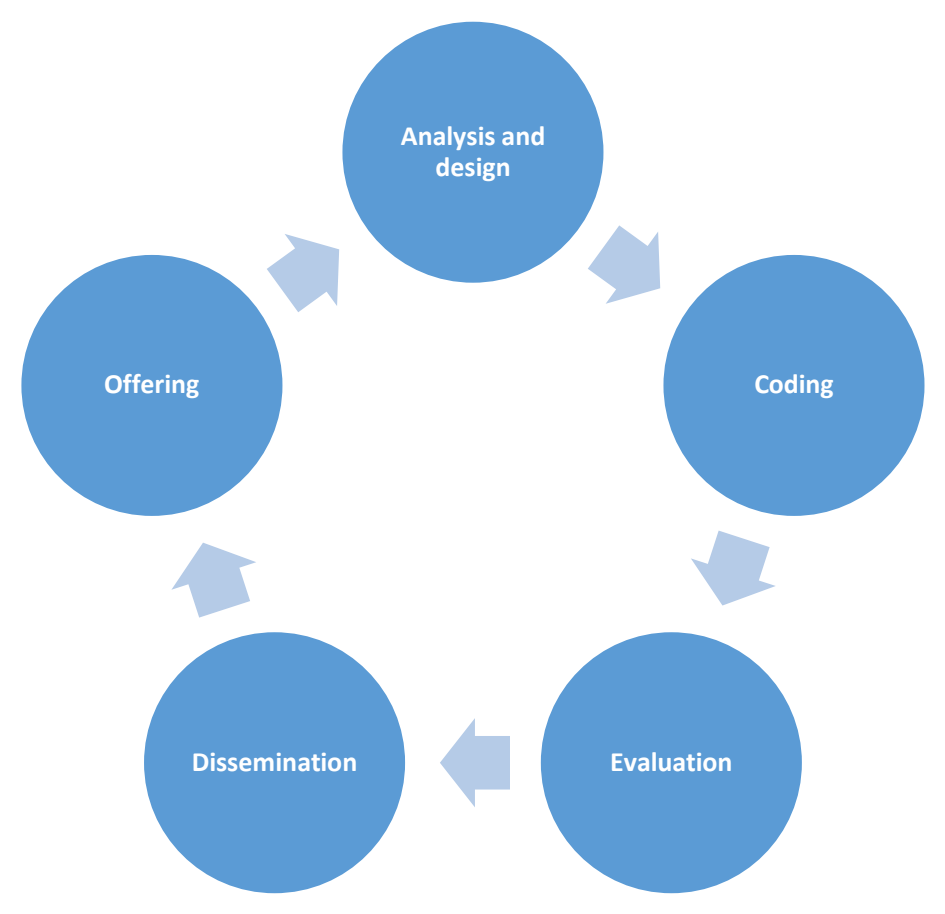

Figure 1. MOOC Production Cycle

At the end of the course, both the production and the offer results of MOOC-PFL were presented to the University managers in order to demonstrate the extent and worldwide exposure a MOOC can bring to the institution. Also, it was aimed to be allowed to continue the project and receive encouragement to develop other projects, to foster innovation in teaching practices and to introduce the institution in the field of research on the theme.

\section{DETAILS OF THE PRODUCTION AND OFFER PROCESS OF MOOC-PFL}

The process of production and offer of MOOC-PFL starts in the stage of analysis and design, it goes through the stages of coding, evaluation and dissemination and ends with the offer of the course.

\section{Analysis and Design}

An interdisciplinary team was established for the production and offer of material, having four members: an expert in educational technology, two experts in teaching Portuguese language for foreigners and an undergraduate student of Languages at the University. It is important to highlight that only one member of the team had previous experience with Distance Learning and OERs and that the innovation brought by MOOC, added to the need of teaching Portuguese for foreigners, motivated everyone. 
The team established the general learning objectives and the level of difficulty: it was decided to offer a course for foreigners who had a minimum A2 level in Brazilian Portuguese, according to the Common European Framework of Reference for Languages (Conselho da Europa, 2001) to improve their reading, writing and listening skills; the target audience would be formed by foreigners between 20 and $\mathbf{4 0}$ years old who wish to improve their knowledge in Portuguese and learn more about the language, work, study and tourism in Brazil; the University structure, such as FURB TV and the Audio Laboratory could be used to record and edit the materials; a Creative Commons CC BY-NC-SA license type would be the chosen for the course, thus delimiting the search for OERs compatible with such license; the course structure would be of $\mathbf{1 6}$ total hours, divided into four modules, one per week, each one containing an introduction, a reading activity, grammar activities, a forum, extra materials and a final activity. The license CC BY-NC-SA allows someone to recontextualize, adapt and create new videos with non-commercial purposes, provided they give work authors proper credit and get license for the new creations under identical terms (Creative Commons, 2016).

The team met weekly for locating videos on Vimeo (http://vimeo.com) repository with consistent license of use: Public Domain, CC BY, CC BY-NC e CC BY-NC-SA (see Creative Commons, 2016). 110 videos were identified and, after screening for clarity in speech, appropriate language to the level of the target audience, download possibility and sound and picture quality, six were selected. Four were used in the introduction of each module and two were used as auxiliary videos.

From the video selected for each module it was established: a) the specific learning objectives and the theme, as described in Table $1 ;$ b) materials and activities of reading, grammar, vocabulary and issues for the final activity and; c) the discussions. In the case of reading activities, some texts and images were found and the exercises were produced. With regard to grammar, it was necessary to produce seven specific videos in which the first step was to write the script.

Table 1. Specific learning objectives for each PPE-MOOC module

\begin{tabular}{ccl}
\hline Modules & Thematic & Learning Objectives \\
\hline 1 & Football & $\begin{array}{l}\text { Distinguish between ser and estar verbs; use the possessive } \\
\text { pronouns; present football as a sport for social integration and part } \\
\text { of Brazilian culture; learn expressions related to football; } \\
\text { Study the regular verbs ending in AR, ER and IR in the present tense; } \\
\text { Study the irregular verb "IR" (go) in the present tense and in the } \\
\text { immediate future; Identify Brazilian food, beverages, main dishes, } \\
\text { desserts, eating habits. } \\
\text { Learn the use of prepositions and vocabulary related to the streets. } \\
\text { Identify parts of the house / apartment. Identify furniture / } \\
\text { appliance parts. Distinguish between perfect and imperfect past. } \\
\text { Identify the importance of conscious consumption. }\end{array}$ \\
\hline Art & Fome &
\end{tabular}

While the course was being structured, it was sought platforms that would provide space for offering MOOCs for free, like the Open Learning (https://www.openlearning.com), CourseSites (https://www.coursesites.com) and Eliademy (https://eliademy.com) platforms. The choice for MiriadaX was made for meeting gratuity requirements, for providing accreditation to the participants, in the acceptable usability and accessibility, for providing interaction/collaboration tools, for having a technical support team and for having over two million base users (MiriadaX, 2016). Added to those aspects, the Regional University of Blumenau has a partnership agreement with Universia, which sponsors the MiriadaX platform. However, for its use, it was required to sign an amendment to the agreement. The MiriadaX platform is maintained by Universia (a network of universities coordinated by Santander bank) and the telecommunications company Telefonica (MartínMonje et al., 2014). The platform makes courses of several themes available and they are offered by 61 Latin American institutions (MiriadaX, 2016). 


\section{Coding Stage}

Each of the six selected videos was transcribed to facilitate the construction of activities. Also, for the four videos used in the introduction parts, it was necessary to add explanations concerning vocabulary. In this action, the Quizlet (https://quizlet.com) application was used, which is a learning tool that allows teachers to create digital flashcards in which the student can hear the pronunciation of words or phrases, and practice writing and reading through the available games. This application can be accessed by Internet-connected devices, as well as being incorporated into the MOOC platform (see more about Quizlet in Lander, 2015). A Quizlet usage example is shown in Figure 2.

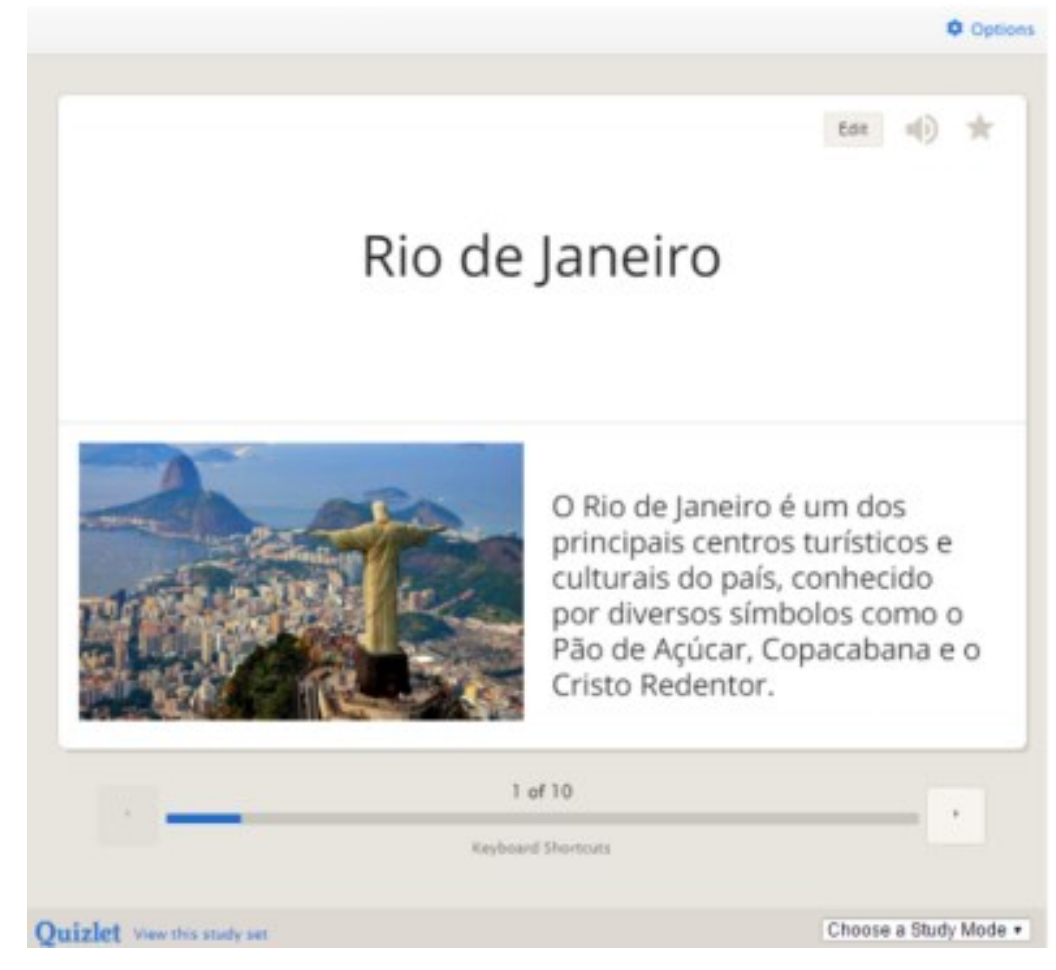

Figure 2. Example of use of the application Quizlet

In the introductory videos it was also used the Playposit application, which allows you to add questions and comments while running a video. This transforms the traditional passivity of watching videos into an active experience for the student (PlayPosit, 2016). Figure 3 shows an example of the application use.

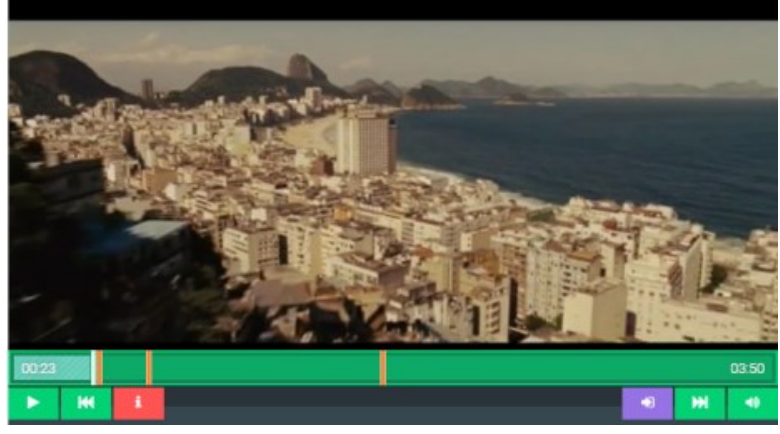

a) Video running

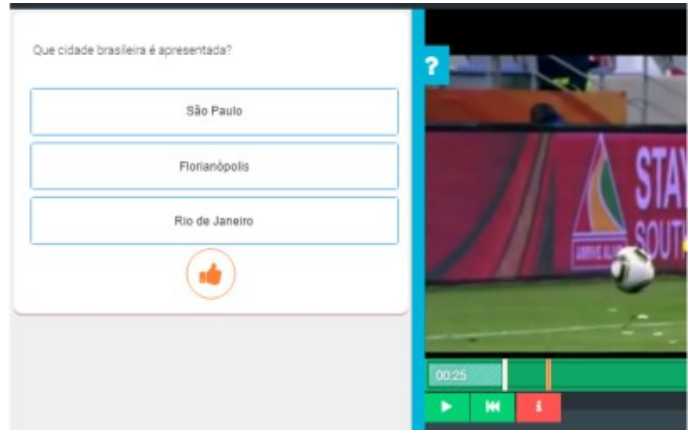

b) Question to be answered

Figure 3. Example of use of the Playposit application 
Regarding the seven new videos produced by the team in order to explain the grammatical content, initially the script was written, then the audio was recorded and finally, with the aid of PowToon (https: //www.powtoon.com/) application, the video was produced.

For both reading and grammar activities, multiple choice exercises were created with the help of the software Hotpotatoes (https://hotpot.uvic.ca/), in which the participant could perform self-assessment tests to check their understanding on the subject. The results of these tests were not counted in the final score, giving freedom to the participants to do them countless times.

Due to the tool restriction offered by MiriadaX (offer the tools: P2P, Wiki, Web pages, Blog, Forum and Quiz) for building activities and materials, it was necessary to structure and incorporate (embed) to the course external platform resources such as: Quizlet and Playposit, videos deposited on Vimeo and activities generated with the help of Hot Potatoes.

For the team to understand the structure of the course as the materials were being produced, these were published in a restricted manner in MiriadaX platform. Also, during the publication of the course on the platform, links were added to additional materials such as videos, texts and activities located on Web sites. At the end of each module, a mandatory activity was created containing multiple choice questions on the studied subjects.

The production team chose to conduct various activities of self-assessment, with automatic correction, which allowed participants to do the course on their own pace on. In addition, social collaborative activities were designed to create some collaborative networks and to encourage an active participation and a sense of belonging to a community besides practicing social learning.

In order to fulfill one of MiriadaX's requirements for spreading a video was produced to publicize the MOOC-PFL, containing the objectives, the required level of knowledge, the course structure and information about the University, and it was also deposited in the Vimeo repository in OER format and subtitled in 10 languages.

\section{Evaluation Stage}

After the publication of the course, in a restricted manner, in MiriadaX platform, team members rated it on its access and on the use of the material produced on Windows, Linux, Android and IOS operating systems, and on computer devices, tablet and smarthphones, not identifying problems in such aspects.

Another evaluation was carried out by the technical staff of MiriadaX, in order to verify whether the premises had been followed by the production team such as: a) recommended workload of studies not over three hours per week; b) the course having at least four modules, and each module being offered once a week; $c$ ) the total of audiovisual content having a minimum length of $\mathbf{3 0}$ minutes; d) each video lasting a minimum of three and a maximum of five minutes; e) the theoretical support material having at least two resources; $f$ ) at least one mandatory assessment being carried out for each module; $g$ ) dynamic discussion in the forums; $h$ ) supplementary materials added; i) captions to videos added. Two adjustments were required: one on the configuration of the mandatory assessment Quiz for each module, allowing up to three attempts by the participant to answer it and another adjustment on the inclusion of subtitles in Portuguese for all the videos used in the course.

\section{Dissemination Stage}

Having overcome the issues related to evaluation and bureaucratic procedures concerning the agreement between the University and the Universia group, the course starting date was set. Later, the course was widespread in portals such as the Brazilian Foreign Ministry, in social networks (Twitter and Facebook), in newspapers and it was made available online, in the institutional University website and by email marketing sent both by the MiriadaX 
platform to its users, as by the University to the sectors of International Relations with foreign institutions and to former students of exchange programs. In addition, it was carried out telephone calls and e-mail contacts with Brazilian companies that knowingly hire foreigners for their production and management processes. The Figure 6 shows the MOOC-PFL Homepage in MiriadaX.
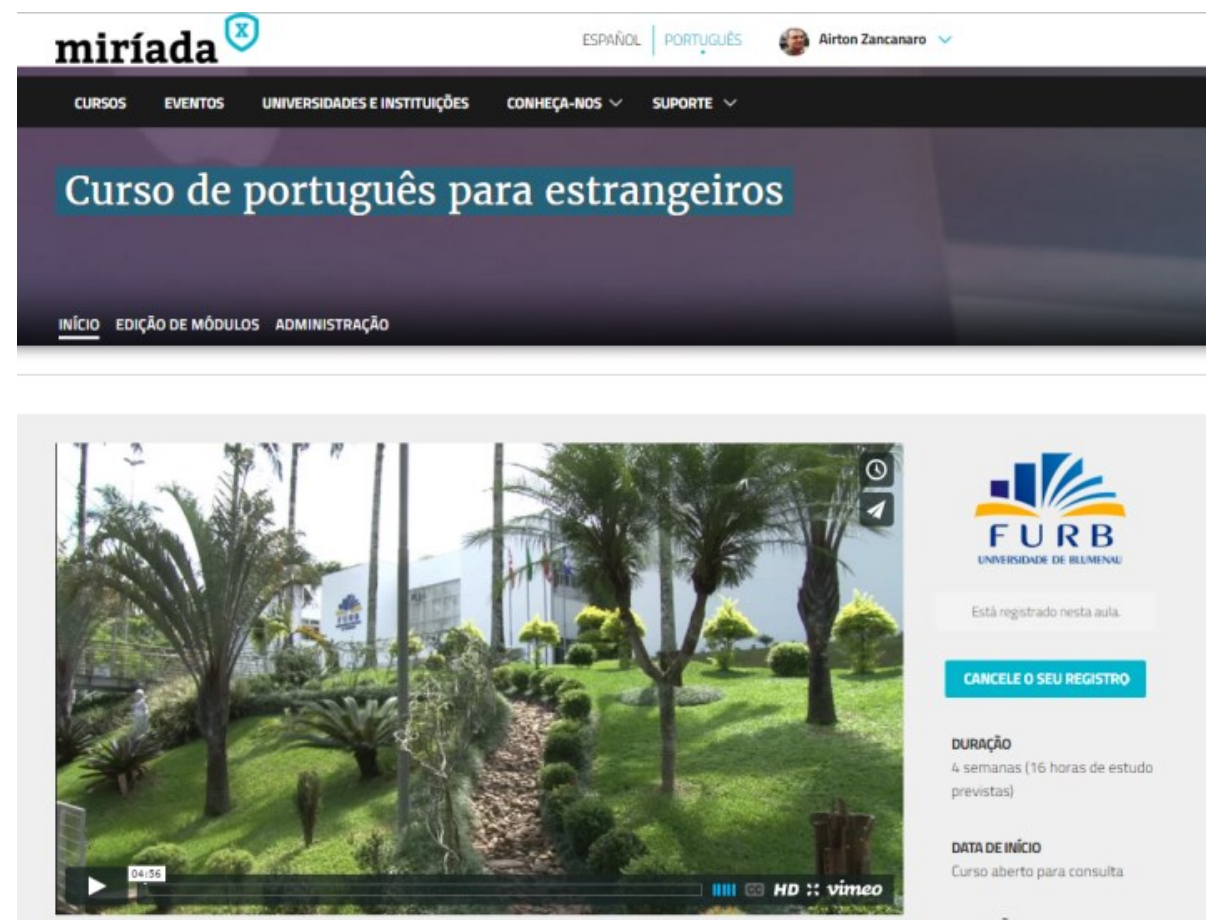

AVRUAÇ̄ôn Do CURSO

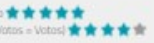

Módulos do curso

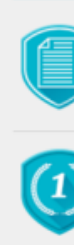

(2)

(4)

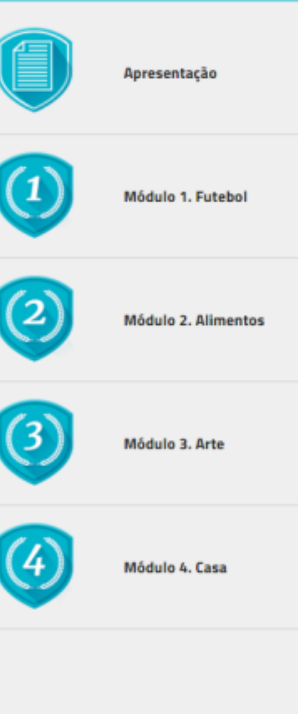

\section{Conhecimento}

Para a realização deste curso o participante deverá ter conhecimentos prévios mínimos Quadro Europeu Comum de Referência para Línguas, ou seja, entende frases em português e se comunica de maneira simples.

\section{Professores}
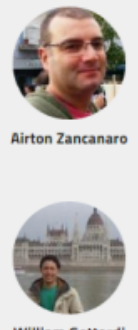

William Gottardi

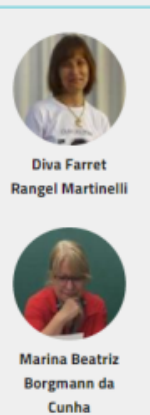

Figure 4. MOOC-PFL Homepage

The dissemination process took place during the three weeks before the beginning of the course, taking proportions which made it difficult to measure the scope of the results on social networks and e-mails. One indication of that was the range of over 15 thousand views of the course presentation video. 


\section{Offering Stage}

The MOOC-PFL course was offered to public between February 15 and March 15, 2016, recording 11,412 registrations, 8,225 starting students and 1,823 students who finished the course within the prescribed period. There were 2,426 messages in the forums and 1,611 members on the Facebook group.

Participants were free to watch the videos, practice the language using the available applications and make posts in the forums, anytime, anywhere. The requirement was that, in the final questionnaires of each module, the participants could obtain at least $50 \%$ of the answers correct in three maximum attempts, which gave them the right to obtain the certificate of participation in the course.

In the first week of the course, a survey was applied in order to identify the participants' profiles. The 3,135 respondents were of 62 different nationalities, being $29.63 \%$ from Spain, $14.61 \%$ from Colombia, $10.56 \%$ from Peru, $9.28 \%$ from Mexico and $7.66 \%$ from Argentina, as illustrated in Figure 7.

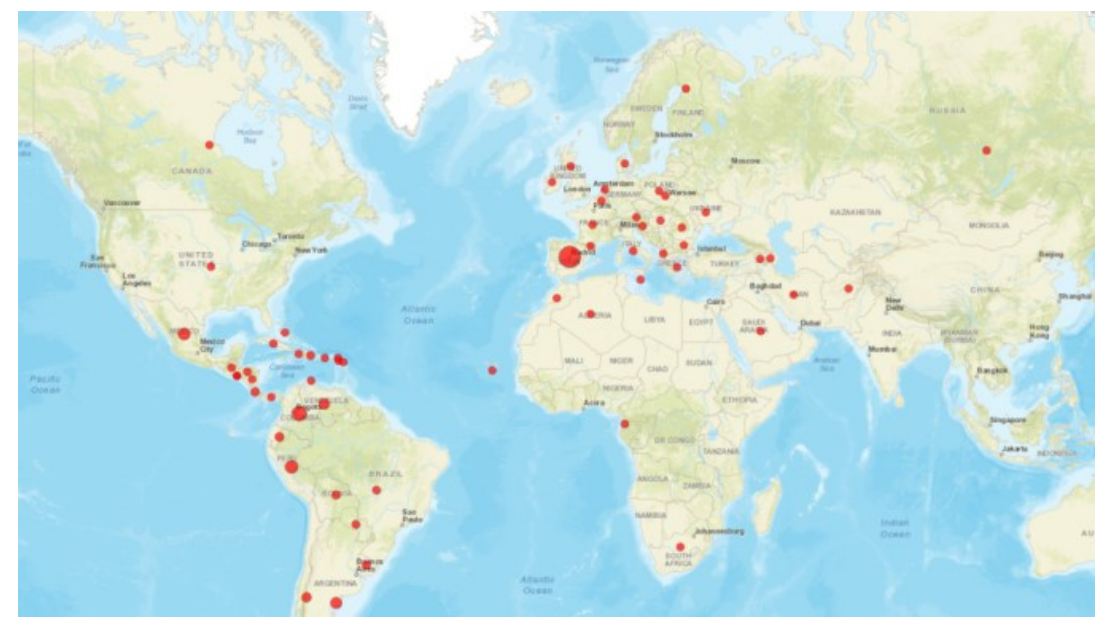

Figure 5. Participants' Nationality Map

As for respondents' demographic data, the age range was concentrated between 20 to 30 years old, being $54.8 \%$ women and $45.2 \%$ men, as shown in Figure 8 . In terms of education, $39.62 \%$ had undergraduate education, $24.69 \%$ were college students, $22.07 \%$ had master degree, 5.93\% were high school students, 5.14\% had a PhD, $2.2 \%$ had other level of education and $0.35 \%$ had just primary education.

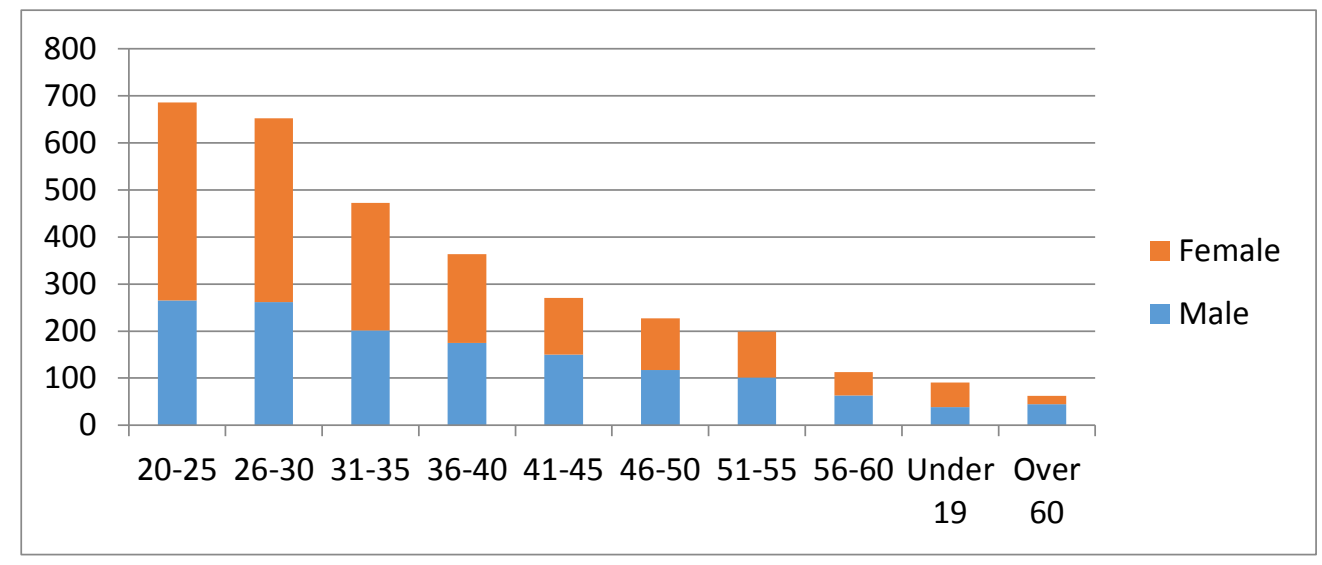

Figure 6. Participants' age and sex chart 
For the respondents, the reasons to practice or improve Brazilian Portuguese were: a desire to know the language (57.86\%); an intention to study in Brazil (12.03\%); willing to know Brazilian culture $(9.06 \%)$; a desire to work in Brazil $(8.74 \%)$; making tourism in Brazil $(8.17 \%)$ and other purposes $(4.15 \%)$.

Regarding the language knowledge level, $32.85 \%$ were A2 (can understand phrases, expressions and communicate simply in situations that require exchange of short and precise information), $24.27 \%$ were A1 (can interact in a simple way with the locals since they speak slowly), $24.24 \%$ have no knowledge of the language, $12.25 \%$ were B1 (can produce simple texts on familiar areas and interest and interaction with native speakers happen effortlessly), $4.11 \%$ were B2 (can understand the main ideas of complex texts and produce clear and detailed texts and express themselves fluently and spontaneously) and $2.26 \%$ were C1 (able to understand long texts and can express themselves fluently and spontaneously).

On the respondents' weekly time availability to do the MOOC-PFL course, $34.64 \%$ reported having up to four hours; $31.71 \%$, two hours; $15.73 \%$, six hours; $9.7 \%$ prefer to do the weekly activities in one day; $7.34 \%$ have eight hours or more and $0.89 \%$ do not have time.

It was noticed that $47.53 \%$ of the respondents have attended other MOOCs, followed by 44.47\% with no prior experience and $8.01 \%$ who know what MOOCs are, but have never attended other courses (Figure 9).

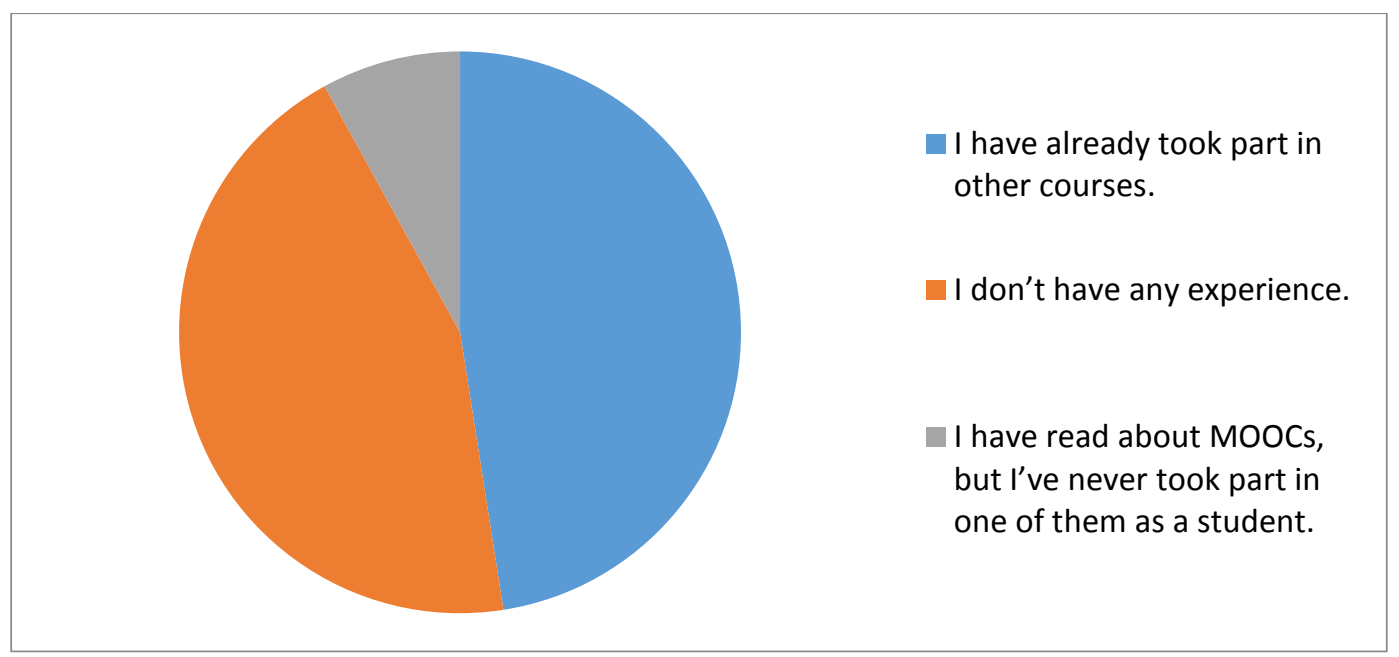

Figure 7. Chart of participants' experience with MOOCs

Another purpose of the questionnaire was to identify some aspects related to: a) the spread of MOOC-PFL in which, $\mathbf{2 7 . 9 1 \%}$ respondents said they got aware of the course existence by email; $25.55 \%$, by searches performed on the Web; $19.23 \%$ by friends' indication; $14.04 \%$, through digital social networks and $13.27 \%$ got aware of the course existence by other means; b) the digital social networks mostly used: Facebook $(70.6 \%)$, Twitter $(7.8 \%), 7.2 \%$ do not use these features, Google + $(6.8 \%)$, Instagram (4.7\%) and $3.1 \%$ used other networks; c) devices used to access the course: computers $(85.5 \%)$, smartphones $(8 \%)$, tablets/Ipads $(6.1 \%)$ and other ones $(0.4 \%)$.

\section{DISCUSSIONS}

The use of the OER production cycle as a basis, proposed by Zancanaro (2015), served as a parameter for the development of the MOOC-PFL, since the team was inexperienced in producing MOOCs and it was the first time this type of course was being offered by the University. The production cycle of OER used as a basis has four stages (analysis and design, coding, use and evaluation and publication). However, to meet the specificities of 
the production and offer of MOOCs, the cycle needed to be adequate and supplemented thus defined as: analysis and design, coding, evaluation, dissemination and offering.

Regarding the use of the OERs in the MOOC-PFL, the following contributing aspects were identified: a) the optimization of production time, as in the case of video selection, meeting the license agreement and the established quality requirements, not being necessary to write scripts, record and edit videos; b) from the videos used as the basis for each module, the definition of the four thematic, enabling the construction of other materials that have also been published as OER; c) starting the team's sensitization process in favor of the reuse of the OERs and demystifying the proper use of licenses.

Producing a MOOC using materials that respect the ethical, legal and quality issues is timeconsuming in terms of locating and producing them, as it requires knowledge of didactics, technologies and distance education. There is a large amount and variety of materials available on the Web these days. However, due to a lack of clear identification of the type of license to use and correct completion of metadata, the proper location and / or reuse of them is harmed.

Still in the analysis stage, defining and designing the type of license to the course and the technological infrastructure for the provision and offer of MOOC-PFL (MiriadaX platform) allowed to delimit the search for OERs in the repositories. It also helped in the planning and structuring of the course, as it was known that the rules and tools are provided by the platform for use, thus enabling time optimization and a dynamic and interactive way to create activities.

Composing an interdisciplinary team and keeping them motivated and engaged in the proposed production and offer of MOOC-PFL demanded from the coordination of the project determination and perseverance to achieve the goals set previously. Weekly meetings for production, participation in other MOOCs and sharing scientific papers on the theme have been some of the strategies to keep staff engaged. Moreover, as materials were produced and published on the platform the team was able to visualize the progress of their work.

One of the purposes for offering a MOOC is to give visibility to it. Choosing a platform that meets the storage and management requirements of the course, with a significant number of users who know and participate in their courses, favors the spread of course offer.

Some limitations were identified in relation to the selected platform for MOOC-PFL. The first was in relation to the form of organization of the messages in the forums, in which there was some difficulty to monitor the feedback given both by the teacher and the participants. To compensate that gap of interaction and dynamics between the participants and teachers / participants, a group was created on Facebook in order to minimize the distance, to have a more meaningful dialogue and to motivate participants to go beyond what was offered in the course. Thus, monitoring was performed both in the platform and in the online social network. Another limitation was the lack of a virtual keyboard that allows a set up to write in Portuguese. Spelling marks / symbols, such as cedilla and tilde, are not common keys on the keyboards of other languages, damaging the participants' production in writing activities.

The funnel effect, presented by Rutenbar (2014), was also observed in the provision of MOOC-PFL. Table 2 shows in numbers that effect. Comparing the rate of completion of MOOCs presented by Schmidt and McCormick (2013), Ding et al. (2014) and Martin-Monje et al. (2014), which ranges from 3\% to 6\%, MOOC-PFL showed a $22.16 \%$ index. 
Table 2. Participants registered per module.

\begin{tabular}{lll}
\hline Module & $\begin{array}{l}\text { Starting } \\
\text { participants }\end{array}$ & $\begin{array}{l}\text { Completing } \\
\text { participants }\end{array}$ \\
\hline Presentation & 6,812 & 6,812 \\
Module 1. Football / Soccer & $\mathbf{7 , 9 1 5}$ & 3,739 \\
Module 2. Food & 3,533 & 2,593 \\
Module 3. Art & 2,568 & 2,202 \\
Module 4. Home & $\mathbf{2 , 2 3 9}$ & $\mathbf{1 , 8 7 9}$ \\
\hline
\end{tabular}

It is possible to notice that 1,103 participants have chosen to start their studies directly in Module 1, disregarding the instructions contained in the presentation of the course. It is also observed that the funnel effect was more significant in this module.

When analyzing the total number of participants who started and finished the MOOC-PFL, the reasons for dropping out are difficult to investigate, and may be due to the curiosity to know the course and its structure, difficulty in understanding the videos by the participant for not being used to listening to Portuguese, technical problems that may have occurred, lack of time to carry out the activities, inexperience in the practice of distance education, different backgrounds, interests and expertise, among others.

During the offering of the course, it was necessary to review the communication and dialogue strategies planned to forums, both in MiriadaX and Facebook, in order to maintain students' interest in the course and encourage the establishment of posts. Addressing issues related to the participant's context, such as posting pictures and describing the city they lived in Portuguese, favored the discussions among participants, knowledge exchange, interculturalism and the development of writing skills in Portuguese. Due to the volume of messages in the forums, it was required full-time staff dedication to the course in an attempt to give fast and individualized feedback.

\section{CONCLUSION AND FUTURE STUDIES}

This study describes the process of production and offer of the MOOC-PFL using OER material, developed by Regional University of Blumenau, aiming to verify whether the framework for OER production focused on knowledge dissemination, proposed by Zancanaro (2015), can also be used for fully producing and offering MOOCs. In relation to the framework used as a basis, it was found that, for the production and offer of MOOCs, the first three phases can be considered as a reference. However, the inclusion of the stages of distribution and offer was necessary in order to organize and optimize the entire process. Martín-Monje et al. (2014) question whether learning a language is an appropriate topic to be addressed in MOOCs. It is understood that producing and offering a MOOC for participants who have the most diverse backgrounds, interests and expertise of a language is a challenge for producers. Therefore, it is necessary to provide support so that learning occurs in the network: someone's experience helps others overcome their difficulties in order to practice a new language together.

The MOOCs may well be a means for teaching languages since: they are properly structured; available on a platform to give visibility; use attractive, updated and high quality materials; offer activities in the forums to consider the context of the participants; are evaluated for technical and scientific reliability; are spread in order to achieve a higher number of participants and are offered with a systematic monitoring team. Considering these aspects can also be useful in the production and offer of MOOCs in other areas of knowledge. The develop and offer of the first MOOC-PFL by the University allowed its insertion and testing in an innovative area expanding and increasing the international visibility, not only of the institution, but also of the city and the state, with indirect gains. 
As for the staff involved in the course, it was required courage, perseverance, dedication and focus to innovate, besides providing intense, challenging, exciting and rewarding experiences in relation to knowledge democratization. The interculturalism experienced, the exchange of experiences, messages of encouragement, recognition for the work, the creation of a new network and the creation of a community interested in the subject are some aspects that makes it possible to positively evaluate the effort made in the production and offer of a MOOC-PFL. For future work, it is recommended a new offer of the course and the production of more advanced levels for the improvement of Brazilian Portuguese, identifying and analyzing the reasons that lead participants to stay motivated until the completion of the course, and developing a specific framework to MOOCs.

\section{BIODATA and CONTACT ADDRESSES of AUTHORS}

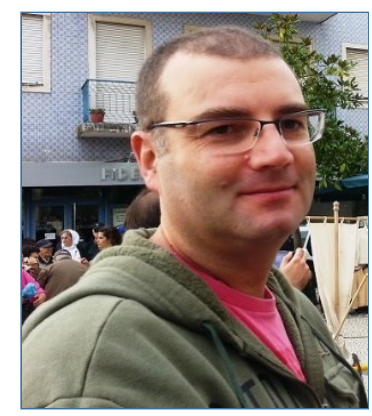

Airton ZANCANARO received an undergraduate degree Computer Science for the Regional University of Blumenau (1999). He completed his Masters in Knowledge Engineering and Managment at the Federal University of Santa Catarina (2011) and Doctorate in Knowledge Engineering and Managment at the Federal University of Santa Catarina (2015). He is currently a professor at the Catarinense Federal Institute (IFC), Campus Sao Bento do Sul. Research interests include Distance Education, Open Education, Open Educational Resources and MOOCs.

\section{Airton ZANCANARO}

Catarinense Federal Institute, Campus Sao Bento do Sul, Paulo Chapiewski, 931, Bairro Centenario,

CEP: 89283-064 Sao Bento do Sul-Brasil

Phone: +55 47 3188-1700

E-mail: airton.zancanaro@ifc.edu.br

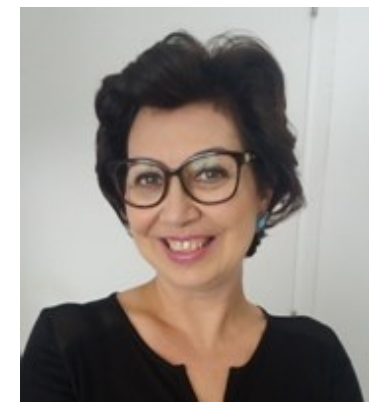

Assist. Prof. Dr. Maria Jose Carvalho de Souza DOMINGUES, Management Department, Regional University of Blumenau, Blumenau, BRASIL. Holds a degree in Management Sciences from the Universidade Federal de Santa Catarina (1986), a Master's degree in Management from the Universidade Federal de Santa Catarina (1991) and Doctoral in Production Engineering from the Federal University of Santa Catarina (2003). Professor at the Universidade Regional de Blumenau / FURB, in the Management Department. Experience in university management and has served as Director of the Center for Business Science, Pro-Reitora of Graduation and coordinator of the Graduate Program in Management of the Universidade Regional de Blumenau / FURB. Research interests include University Management and Technologies in Teaching.

Maria Jose Carvalho de Souza DOMINGUES

Management Department, Universidade Regional de Blumenau, Antonio da Veiga, 140, CEP:892030-903 Blumenau-BRAZIL

Phone: +55 47 3321-0565

E-mail: mariadomingues@furb.br

\section{REFERENCES}

Ahlberg, C. (2014). MOOCs at Karolinska institutet university library. Insights, 27(2), 160165.

Angell, C., Hartwell, H., \& Hemingway, A. (2011). The emergence of public health open educational resources. Health Education, 111(4), 256-265. 
Banzato, M. (2012). A case study of teachers' open educational practices. Journal of ELearning and Knowledge Society, 8(3), 153-163.

Burigo, C. C. D., Cerny, R. Z., Teixeira, G. G. S., \& Marcelino, L. V. (2016). A gestao colaborativa no processo formativo da EaD. Revista GUAL, $9(1), 165-176$.

Chen, Q. (2010). Use of Open Educational Resources: Challenges and Strategies. In P. Tsang, S. K. S. Cheung, V. S. K. Lee \& R. H. Huang (Eds.), Hybrid Learning (Vol. 6248, pp. 339-351).

Chen, Y. (2014). Investigating MOOCs Through Blog Mining. International Review of Research in Open and Distance Learning, 15(2), 85-106.

Clarke, T. (2013). The advance of the MOOCs (massive open online courses): The impending globalisation of business education? Education and Training, 55(4), 403-413.

Claros, I., Cobos, R., Guerra, E., De Lara, J., Pescador, A., \& Sanchez-Cuadrado, J. (2013). Integrating open services for building educational environments. 2013 IEEE Global Engineering Education Conference, EDUCON 2013, Berlin.

Comeau, J. D., \& Cheng, T. L. (2013). Digital "tsunami" in higher education: Democratisation Movement towards Open and Free Education. Turkish Online Journal of Distance Education, 14(3), 198-224.

Conselho da Europa. (2001). Quadro europeu comum de referência para as línguas: Aprendizagem, ensino, avaliaçao. Porto: Edições ASA.

Creative Commons. (2016). Sobre As Licenças. Retrieved 15 Abr 2016, 2016, from http://creativecommons.org/licenses/

Ding, Y., Wang, M., He, Y., Ye, A. Y., Yang, X., Liu, F., Wei, L. (2014). "Bioinformatics: Introduction and Methods," a Bilingual Massive Open Online Course (MOOC) as a New Example for Global Bioinformatics Education. PLOS Computational Biology, 10(12).

Eckerdal, A., Kinnunen, P., Thota, N., Nylen, A., Sheard, J., \& Malmi, L. (2014). Teaching and learning with MOOCs: Computing academics' perspectives and engagement. 2014 Innovation and Technology in Computer Science Education Conference, ITICSE 2014, Uppsala.

Goldberg, E. J., \& LaMagna, M. (2012). Open educational resources in higher education: A guide to online resources. College and Research Libraries News, 73(6), 334-337.

Iqbal, S., Zang, X., Zhu, Y., Chen, Y. Y., \& Zhao, J. (2014). On the impact of MoOCs on engineering education. 2014 IEEE International Conference on MOOCs, Innovation and Technology in Education, IEEE MITE 2014.

King, C., Doherty, K., Kelder, J.-A., McInerney, F., Walls, J., Robinson, A., \& Vickers, J. (2014). «Adecuacion al proposito»: un enfoque centrado en el colectivo de estudiantes para el diseno de un curso en línea masivo y abierto (MOOC). RUSC Universities and Knowledge Society Journal, 11(3), 113-127.

Kumar, A., KanikaPhutela, NehaSrivastava, Singar, S., \& Ieee. (2013, 2013). The Impact of Linux (Free Open Source Software) in Spoken-Tutorial a Part of "MOOC". Proceedings of the 2013 Ieee International Conference in Mooc, Innovation and Technology in Education (Mite).

Lander, B. (2015). Lesson study at the foreign language university level in Japan". International Journal for Lesson and Learning Studies, 4(1), 362 - 382.

Leontyev, A.\& Baranov, D. (2013). Massive open online courses in chemistry: A comparative overview of platforms and features. Journal of Chemical Education, 90(11), pp 1533-1539. 
Levy, D., \& Schrire, S. (2013, 2013). Considering moocs at a college of education: narrative of disruptive innovation? Edulearn13: 5th International Conference on Education and New Learning Technologies.

Martín-Monje, E., Barcena, E., \& Read, T. (2014). La interaccion entre companeros y el feedback lingüístico en los COMA de lenguas extranjeras. Profesorado, 18(1), 167-183.

Mihaescu, V., Vasiu, R., \& Andone, D. (2014). Developing a MOOC: The Romanian experience. Proceedings of the European Conference on e-Learning, ECEL.

MiriadaX. (2016). Nossa filosofia. Retrieved 14 Abr. 2016, 2016, from https: //miriadax.net/web/guest/nuestra-filosofia

Nissenson, P. M., \& Shih, A. C. (2015). MOOC on a budget: Development and implementation of a low-cost MOOC at a state university. 122nd ASEE Annual Conference \& Exposition, Seattle.

Nunes, C. S., Rissi, M., Nakayama, M. K., \& Pacheco, A. S. V. (2015). Compartilhamento de conhecimento: os meios utilizados no contexto da educaçao a distância. Revista GUAL, 8(1), 68-85.

O'Connor, K. (2014). MOOCs, institutional policy and change dynamics in higher education. Higher Education, 68(5), 623-635.

Pantò, E., \& Comas-Quinn, A. (2013). The challenge of open education. Journal of ELearning and Knowledge Society, 9(1), 11-22.

Parkinson, D. (2014). Implications of a new form of online education. Nursing Times, 110(13), 15-17.

PlayPosit. (2016). Interactive Video Learning. Retrieved 14 Abr. 2016, 2016, from https://www.playposit.com/

Pujar, S. M., \& Bansode, S. Y. (2014). MOOCs and LIS education: A massive opportunity or challenge. Annals of Library and Information Studies, 61(1), 74-78.

Rodriguez, C. O. (2013). Two distinct course formats in the delivery of connectivist moocs. Turkish Online Journal of Distance Education, 14(2), 66-80.

Rodriguez, C. O. (2014). Mobimooc 2012: A new tree structure for the delivery of connectivist moocs. Turkish Online Journal of Distance Education, 15(1), 41-49.

Rutenbar, R. A. (2014). The first EDA mooc: Teaching design automation to planet earth. 51st Annual Design Automation Conference, DAC 2014, San Francisco, CA.

Sangrà, A., \& Wheeler, S. (2013). Nuevas formas de aprendizaje informales: ¿O estamos formalizando lo informal? RUSC Universities and Knowledge Society Journal, 10(1), 286-293.

Santos-Hermosa, G., Ferran-Ferrer, N., \& Abadal, E. (2012). Recursos educativos abiertos: repositorios y uso. Profesional de la Informacion, 21(2), 136-145.

Schmidt, D. C., \& McCormick, Z. (2013). Producing and delivering a MOOC on patternoriented software architecture for concurrent and networked software. 4th Annual ACM International Conference on Systems, Programming, Languages, and Applications: Software for Humanity, SPLASH 2013, Indianapolis, IN.

Stikkolorum, D. R., Demuth, B., Zaytsev, V., Boulanger, F., \& Gray, J. (2014). The MOOC hype: Can we ignore it? Reflections on the current use of massive open online courses in software modeling education. MODELS Educators Symposium, EduSymp 2014 - Co-located with the ACM/IEEE 17th International Conference on Model Driven Engineering Languages and Systems, MODELS 2014.

Stuchlíkova, L., \& Kosa, A. (2013). Massive open online courses - Challenges and solutions in engineering education. 11th IEEE International Conference on Emerging eLearning Technologies and Applications, ICETA 2013, Stara Lesna. 
Spector, J. M. (2014). Remarks on MOOCS and Mini-MOOCS. Educational Technology Research and Development, 62(3), 385-392.

Stark, C. M., \& Pope, J. (2014). Massive open online courses: How registered dietitians use moocs for nutrition education. Journal of the Academy of Nutrition and Dietetics, 114(8), 1147-1151.

Hylen, J. (2006). Open Educational Resources: Opportunities and Challenges (pp. 10). Paris, França: Organisation for Economic Co-operation and Development (OECD).

UNESCO (2002). Forum on the Impact of Open Courseware for Higher Education in Developing Countries (pp. 30). Paris, França: UNESCO.

UNESCO (2012). Declaraçao REA de Paris em 2012 (pp. 2). Paris, França: UNESCO.

Weller, M. (2014). The Battle for Open: How openness won and why it doesn't feel like victory. Londres: ubiquity press.

Zancanaro, A. (2015). Um framework para a produçao de Recursos Educacionais Abertos com foco na disseminaçao do conhecimento. (Doutorado Tese), Universidade Federal de Santa Catarina, Florianopolis. 